\title{
Om å tre inn som en feil i samtalen
}

\author{
En drefting av de demokratiske muligheter $i$ å \\ unndra seg skolens inkludering
}

\author{
Av Rannveig Oliv Myhr
}

I denne artikkelen drefter jeg hvordan det kan vere utfordrende for elever å skulle gi et språklig uttrykk for en religiøs tro $i$ de sivile offentlige samtaler $i$ skolen og hvordan det $i$ sammenheng med det kan tolkes som en demokratisk handling å trekke seg ut av samtaler $i$ skolen. Jeg benytter meg i artikkelen av eksempel på troserfaringer hentet fra skjønnlitteratur og essays for å billedliggjøre noen av de utfordringer elever med en religiøs tro kan stå overfor $i$ skolens offentlige samtaler hvis religiøse troserfaringer skal spräkliggjøres.

Nøkkelord: Utdanning, demokrati, offentlige samtaler, motstand, religiøs tro

RanNVEIG Oliv Myhr (f. 1964), forstelektor ved Institutt for laererutdanning, NTNU. Gunnerus gate 1, 7012 Trondheim.E-post: rannveig.oliv.myhr@ntnu.no

\section{DET PEDAGOGISKE ØNSKET OM DELTAKELSE}

I en artikkel om metaforen «safe space» drøfter Karin Kittelmann Flensner og Marie von der Lippe om «classroom of disagreement» kan være en mer egnet metafor hvis vi ikke ønsker å gi elever falske forventninger om trygghet i klasseromssamtaler, men isteden vil gjøre det tydelig at uenighet er en del av livet og vil være en del av livet i klasserommet også (Flensner, von der Lippe 2019). Artikkelen bygger på empiriske undersøkelser fra norsk og svensk skole og omhandler diskusjoner i bl.a. religions- og livssynsundervisningen. I et eksempel de henter ifra forskningsmaterialet, skildres en jente som etter et undervisningsopplegg der elevene har diskutert ytringsfrihet, blir funnet gråtende ute i korridoren av læreren. Til tross for at jenta stiller seg bak undervisningsopplegget og ønsker at de skal kunne diskutere ytringsfrihet, så føler hun seg såret av det språket og de eksemplene som blir brukt om blant annet islam, som er hennes religion. I et annet eksempel skildres det hvordan en gruppe gutter opplever polariseringen i klasseromsdiskusjonene som så sterk at de finner det best å tie stille med sine synspunkter fordi de politisk er relativt langt til høyre. For lærerne er det et dilemma at de både skal sørge for at klasserommet preges av et intellektuelt mot der elever lærer å bli utfordret og å utfordre, samtidig som de skal sørge for at det hele skjer på et trygt vis der den enkelte elevs verdighet tas vare på. Spesielt kan det i sekulære land som Sverige og Norge, der religion stort sett oppfattes som noe privat og personlig, bli vanskelig for elever å bringe religiøs tro inn i klasseromsdiskusjoner. Desto

Prismet - IKO-Forlaget 2020

Tilgjengelig på https://journals.uio.no/index.php/prismet. Publisert under CC BY-NC 4.0. Fagfellevurdert 
viktigere mener Flensner og von der Lippe at det kan være å forberede elevene på at nettopp klasserommet er et «classroom of disagreement» og at uenighet er nødvendig for rasjonelle diskurser (Flensner, von der Lippe 2019).

\section{OM UBEHAGET I DELTAKELSE}

Empirien som Flensner og von der Lippe bygger drøftingen på, peker mot at en del elever i den norske skolen trolig kan oppleve det som belastende å delta $\mathrm{i}$ skolens offentlige samtaler blant annet på grunn av sterke polariseringer i diskusjonene, maktforhold mellom elevene og måter synspunkter blir uttrykt på og eksemplifisert (Flensner, von der Lippe 2019). Eksemplet jeg har benyttet innledningsvis, får fram at det kan være ekstra krevende for elever med en religiøs tro, fordi religiøs tro oppleves som privat og som en del av elevens identitet. Flensner og von der Lippe forstår imidlertid læring og intellektuell utvikling som avhengig av at elevene er i stand til å utholde ubehag og usikkerhet (Flensner, von der Lippe 2019). Dette er forståelser av læring som jeg mener vi kan gjenfinne i den pedagogiske tenkningen til blant annet Thomas Ziehes (2008) og hans begrep ambivalente læringsprosesser, og Gerd Biestas (2009) forståelse av utdanning som «violation» i betydningen forstyrrelser eller innblandinger i elevenes liv. I artikkelen kan Flensner og von der Lippe forstås som å ta et pedagogisk standpunkt til at det å sosialisere til å delta og ikke trekke seg unna, det å diskutere og ikke tie, er viktig for demokratiske klasseromssamtaler. Jeg deler Flensner og von der Lippes oppfatning av at det er viktig at skolen sosialiserer til demokratiske praksiser. Jeg skal i den foreliggende artikkelen imidlertid drøfte hvordan motsatte handlinger av de som Flensner og von der Lippe trekker fram, også kan ha en demokratisk betydning. Med motsatte handlinger mener jeg at elever trekker seg ut av samtaler ved for eksempel å vise liten interesse, ikke ville delta, tie stille. Dette er tilbaketrekning som jeg ikke tolker som å handle om at elever trekker seg unna ubehag og usikkerhet i de felles samtaler i klassen, men som isteden handler om å si nei takk til samtaler der det blir vanskelig å skape nye begynnelser eller forståelser. Det er med andre ord en desinteresse eller disengasjement som kan betraktes som en demokratisk handling (Simons, Masschelein 2010). Det siste kan forstås som å våge å innse at de eksisterende felles forståelser eller språket i de felles samtalene ikke gir rom for å skape nye forståelser hverken for eleven selv eller for andre. Flensner og von der Lippes viktige artikkel gir meg sånn sett et godt utgangspunkt for både å slå følge med deres prioritering av skolens demokratiske praksiser, og for å opprette en distinksjon. Det siste kan åpne for en drøfting av et dilemma som kan ligge $i$ at både ubehag og usikkerhet knyttet til å delta og ta ordet, og til å trekke seg unna og tie, kan ha et demokratisk potensial, men på ulike vis og vurdert på bakgrunn av ulike forståelser av demokrati. 


\section{OM DE DEMOKRATiske MUlighetene I A UNNDRA SEg DE OFFENTLIGE SAMTALER I SKOLEN}

Drøftingen i denne artikkelen skal dreie seg om den demokratiske handlingen som kan ligge $i$ at elever med en religiøs tro trekker seg tilbake fra de sivile offentlige samtaler i skolen ${ }^{1}$. Jeg er som pedagog opptatt av at skolen skal være et sted for sivile samtaler, men jeg er opptatt av at elevenes sosialisering eller inkludering inn i samtalene ikke er uproblematisk. Jeg hegner med andre ord om skolen som en sivil offentlighet ved å forholde meg kritisk til den. Dette er en kritikk som elever trolig også kan målbære i de tilfeller der de viser desinteresse eller disengasjement for samtalene. De offentlige sivile samtalene i skolen kan forstås som demokratiske praksiser, men de kan også kritiseres for å bygge på en felles identifikasjon med lite plass for det som for elevene kan oppfattes som vanskelig å identifisere, men som likevel oppleves som viktig (Simons, Masschelein 2010). Slik sett kan elevers desinteresse og disengasjement, det jeg velger å kalle unndragelser (Myhr, Øksnes 2013), forstås som handlinger som spiller seg ut overfor det begrepet demokrati opprinnelig betyr (Simons, Masschelein 2010). Det siste handler hovedsakelig om at demokrati i utgangspunktet betydde å kunne delta uten å måtte identifisere seg med eller være kompetent på det som er utbredt, akseptert og dominerende (Simons, Masschelein 2010). Når elever ikke opplever at det siste er mulig, men at de isteden skal skoleres, komme til enighet med, oversette eller legge til side det som oppleves som viktig, og kanskje ennå ikke er gjort identifiserbart, så kan desinteresse og disengasjement forstås som demokratiske handlinger i den betydning at de etterlyser å kunne få delta uten å måtte kvalifisere seg for en eksisterende orden.

Skolen kan altså forstås som en institusjon som kvalifiserer eleven for å ta del i bredere offentlige debatter, den sivile offentlighet. Skolens demokratiske oppgave kan med andre ord forstås som en kvalifiseringsoppgave. Flensner og von der Lippes (2019) artikkel leser jeg som en drøfting av det som kan kalles spenninger innenfor denne kvalifiseringsoppgaven. Innenfor deler av pedagogikken føres det imidlertid også en kritikk av en vekt lagt på kvalifisering av elevene for de sivile offentlige samtaler, fordi det kan bidra til en "governmentalisation of democracy» (Simons, Masschelein 2010). Dette er en kritikk og en forståelse av demokrati som dreier seg om at enhver kan blande seg inn i den sivile offentlige samtalen uten å være kvalifisert eller kompetent, det vil si uten å være en del av den eksis-

1 I denne artikkelen forstår jeg samtaler mellom elever på skolen, blant annet som en del av undervisningen, som sivile offentlige samtaler. Skolen forstått som en sivil offentlighet drøftes av blant annet religionssosiologen Pål Ketil Botvar (2010). Han forstår skolen som både en statlig-politisk offentlighet og en sivil offentlighet (Botvar 2010). Den statlige og politiske offentlighet kan relateres til beslutningsprosesser og maktutøvelse, mens den den sivile dreier seg om de bredere offentlige debatter. Den sivile offentlighet befinner seg mellom staten og de enkelte borgere, der det private gjøres offentlig og bidrar til demokratiet gjennom sine debatter (Furseth 2015). Ifølge Botvar kan lærere i større grad bli oppfattet som en statlig offentlighet og elevene som en sivil offentlighet (Botvar 2010). 
terende orden. Gjennom å blande seg inn i samtalen, uten å være kvalifisert, vil den som blander seg inn, manifestere seg som en feil og dermed fă fram hva samtalene tar for gitt, og at det finnes en «utside» (Simons, Masschelein 2010). I denne artikkelen blir også det å tie, eller ikke ville delta og engasjere seg i samtaler i skolen, forstått som å manifestere seg som en feil. For pedagogikken kan det være viktig å ha et demokratisk blikk for at elevers desinteresse når det gjelder å bli integrert i skolens samtaler kan forstås som en demokratisk handling som kan gjøre oss oppmerksom på at samtalene har en «utside».

Det vil i denne artikkelen handle om elevers muligheter for å trekke inn i skolens sekulære sivile samtaler det som kan kalles mysteriet Gud (Fosse, Skjeldal 2015). Det siste er knyttet til større overordnede spørsmål som blant annet Craig Calhoun, Mark Juergensmeyer og Jonathan van Antwerpen (2011:18-19), med referanse til Jürgen Habermas, formulerer som hvorvidt det er mulig å delta $\mathrm{i}$ skolens felles samtaler med det som kan være særegent ved en religiøs tro hvis det skal oversettes til eller kvalifiseres for et sekulært språk. Jeg har ikke til hensikt å gå inn i en grunnleggende diskusjon om religionens plass i sekulære samtaler, men det kan, om ikke annet, være hensiktsmessig å ha oversettelsesproblemet som et bakteppe for den drøftingen jeg giør. Jeg bruker derfor litt plass på tematikken her innledningsvis.

Forventninger om oversettelse kan forstås i sammenheng med det demokratiske ønsket om at forskjellige ideologier og sekulære og religiøse trosretninger skal kunne snakke sammen. Til det trengs et felles språk. I en sekulær verden står det sentralt å blant annet gi begrunnelser, føre kritikk, skaffe til veie kunnskap og oppnå sikkerhet. Det kan bety at elever med en religiøs tro møter forventninger om at de kan delta med sin religiøse tro så fremt de er villige til å la troen prøves, kritiseres, avkreves begrunnelser osv. ${ }^{2}$ Men religiøs tro kan være mer knyttet til mysterium enn til begrunnelser, mer til stemninger og «kjensler» enn til kunnskap, mer til tillit enn til kritikk og mer til risiko enn til sikkerhet. Det kan være noe det er vanskelig å forhandle om og komme til en enighet om. For det andre vil paradoksalt nok disse særegenhetene ved religiøs tro kunne gi en trygghet til nettopp å reise kritikk, vie oppmerksomhet til «kjensler» og stemninger som kan stille spørsmål ved etablert kunnskap. Ideer med røtter i religion kan gi nye meninger, nye innsikter og nye identiteter. Det å bidra med religiøse troserfaringer kan løfte fram og klargjøre samfunnsinstitusjoner som det er vanskelig for

2 I forventningen om oversettelse forstås religion som noe som kan forandres i møtet med forventninger til hvordan deltakelse kan skje i demokratiske offentlige samtaler. Det kan dreie seg om at religion generelt sett bør endre seg for å kunne delta (Henriksen, Smith 2010:92) eller at endringer kan gjelde enkelte sider og avgjøres fra en konkret situasjon til en annen (Botvar 2010). Innenfor oppfatninger av at religion kan inkluderes i de offentlige samtaler, forstås religion ikke som essensiell eller uforanderlig. Når jeg i denne artikkelen løfter fram det problematiske i at deltakelse forutsetter kvalifisering (Simons, Masschelein 2010), så mener jeg med det ikke at religion er uforanderlig eller essensiell. Men jeg er opptatt av hvordan deltakelse med en religiøs tro kan bidra til å føye noe til samtalen istedenfor å føye seg inn i den. 
et sekulært blikk å få øye på og gjøre eksplisitt (Calhoun, Juergensmeyer \& van Antwerpen 2011:18-19). Likevel kan det trolig være krevende for elever å bringe inn en religiøs tro i en samtale med sekulære rammebetingelser fordi den religiøse troen kan trenge et annet språk enn det språket som kan bli avkrevd for å delta i offentlige demokratiske samtaler ${ }^{3}$. Kanskje kan det også være vanskelig for eleven selv å språkliggjøre troen overfor seg selv. ${ }^{4}$

Hva som kan sies og tenkes, kan også være et spørsmål om makt. Inkludering i skolens samtaler kan lett bli en inkludering til å bringe inn det som allerede er identifisert, det som kan gjenkjennes og forstås, mens det kan være lite plass til det ennå ikke identifiserbare, til nye handlinger og forståelser som må legges til det allerede eksisterende (Simons, Masschelein 2010). De danske pedagogene Laura Gilliam og Eva Gulløv og de belgiske pedagogene Maarten Simons og Jan Masscheleins er eksempler på pedagoger som fører drøftinger om hvordan myndigheter kan utøve makt gjennom å sosialisere til identifikasjon gjennom skolens sosialiseringsprosesser (Gilliam, Gulløv 2015, Simons, Masschelein 2010).

Innenfor pedagogikk og ungdomsforskning har jeg tidligere skrevet om og tolket elevers unndragelser fra skolens offentlige samtaler som motstand. I samarbeid med Maria Øksnes har jeg tatt til orde for at demokrati ikke behøver handle om å inkludere eller bli inkludert i fellesskapet, men også kan handle om en gruppes skapelse av en identitet som ikke har eksistert tidligere. Å unndra seg, ikke ville bli inkludert, kan bety at eleven sier nei til de eksisterende tilbud og sier ja til selv å skape i den tilbaketrekningen som unndragelsen gir (Myhr, Øksnes 2013). Omskrevet til temaet elever med religiøs tro kan unndragelse fra inkluderende offentlige samtaler i skolen eller fra forventninger om å oversettes for å bli inkludert, forstås i sammenheng med at elever kan oppleve det vanskelig å føye noe til, istedenfor bare å føye seg inn i, det språket eller forståelsen som allerede

3 Det er elevers mulighet til å språkliggjøre tro og religiøse erfaringer som står i forgrunnen i denne artikkelen.

Men jeg har ikke rettet oppmerksomheten mot elevers mer argumenterende eller bevisførende deltakelse i skolens felles samtaler, for eksempel når det gjelder Guds eksistens. Det siste kan gjelde mer religionsfilosofiske og naturvitenskapelige argumenter slik jeg forstår at for eksempel teologen Atle Ottesen Søvik arbeider med dette (Søvik 2018). I den foreliggende artikkelen handler det mer om «how religion works» (Library Foundation of Los Angeles 2012, 20:15), om «faith» i betydningen å «ha tro på deg», en relasjon og et engasjement, enn om «believe» i betydningen å tro at det for eksempel finnes spøkelser (Žižek 2001: 109-110). Jeg har videre ikke laget en distinksjon i denne artikkelen mellom tro som «showing», praktisering av regler, og tro som «saying», en indre bekjennelse, religiøse erfaringer osv. (Žižek 2001:110, 128-129)

4 Kanskje kan det være enklere å finne et felles språk med andre hvis det legges vekt på moralske og allegoriske sider ved religion heller enn religion erfart som tro og mysterium (Fosse og Skjeldal 2015). Religion kan av omgivelsene også oppfattes som mer eller mindre «reasonable» og der mer «reasonable» religionsutøvere kan oppfattes som lettere å inkludere i de offentlige sekulære samtaler enn de som oppfattes som «irrational enthusiasts» (Calhoun m.fl.2011:8, Taylor 2011: 35, Domínguez 2017:278). Jeg vil imidlertid utover i artikkelen oppta meg med at elever med en religiøs tro kan bevege seg mellom det sekulære og hellige i sin hverdag. Jeg har imidlertid ikke, i denne artikkelen, tatt for meg de mange betydningene av sekularisering og begrepet sekulær tro (Calhoun m.fl.2011, Taylor 2011). Isteden har jeg begrenset meg til å rette oppmerksomheten mot religiøs tro mens jeg arbeidet parallelt med en artikkel der sekulær tro står sentralt. 
eksisterer i samtalene. Å trekke seg unna, gjøre motstand, si nei til å delta i skolens offentlige samtaler kan med andre ord oppfattes som å si ja til å trekke seg tilbake for å skape språk og identitet, for seg selv og for andre, når det gjelder å være en elev med en religiøs tro.

\section{OM ARBEIDET MED ARTIKKELEN, SKRIVING SOM FORSKNINGSVERKTØY OG BRUK AV ULIKE SPRÅKSJANGRE}

Jeg skal i fortsettelsen benytte et essay av Bjarte Breiteig (2016) og en roman av Thomas Espevik (2017) for å eksemplifisere og konkretisere hvor krevende det kan være å gi uttrykk for religiøs tro ${ }^{5}$. I tillegg er tekstene, slik jeg ser det, gode uttrykk for menneskelige erfaringer med religiøs tro. Skulle jeg gjort et intevju med elever om religiøs tro i sammenheng med de felles samtalene i skolen, så ville en språkliggiøring av deres erfaringer med religiøs tro stått sentralt. I denne artikkelen har jeg imidlertid valgt å la de to skjønnlitterære forfatternes tekster få eksemplifisere en språkliggjøring av religiøse troserfaringer. Dette valget har sin begrunnelse i både tvil, respekt og i en tanke om en forberedelse til en fortsettelse. Jeg har vært i tvil om jeg ville klart å få elever i tale om religiøs tro, både som erfaring og som språklig utfordring i de felles samtalene i skolen. Men det kan også være å vise respekt for elevenes erfaringer å la ordkunstnere som er bedre i stand til å gi uttrykk for våre menneskelige livserfaringer enn det vi selv er, få uttrykke noe av det elever antakelig kan erfare (Ystad 2019:13). Gjennom arbeidet med denne artikkelen har jeg også blitt mindre i tvil om at jeg i en fortsettelse kan få til å intervjue elever om deres religiøse tro og skolens offentlige samtaler, men at det nettopp er arbeidet med de skjønnlitterære tekstene som har bidratt til å se en slik mulig fortsettelse. Jeg vil også trekke fram at skjønnlitteratur og essays i seg selv kan tolkes som en form for unndragelse. Med andre ord ligger det en dobbelthet $\mathrm{i}$ det at jeg bruker innholdet i skjønnlitterære og essayistiske fortellinger til å eksemplifisere og drøfte elevers unndragelser, samtidig som disse tekstene i seg selv trolig også kan forstås i sammenheng med forfatteres unndragelsesprosesser. Det skal til slutt sies at gjengivelse av og sitater fra Breiteigs (2016) og Espeviks (2017) tekster krever forholdsvis mye plass i artikkelen, og at dette er gjort for at leseren skal få «en viss førstehånds kjennskap» til og erfaring med særpreget til de skjønnlitterære og essayistiske kildene (Anders Johansen 2019:26).

Lik språkdidaktikeren Irmelin Kjelaas forstår jeg språk og skriving som mitt forskningsverktøy, og at utforskningen i artikkelen mye ligger i å skrive fram

$5 \quad$ Etter å ha funnet fram til romanen Hva ville Johannes gjort? av Thomas Espevik (2017) tok jeg kontakt med ham om litteratur som kan omhandle noen av de samme temaene som hans roman. Det ledet videre til romanen En prests dagbok av Sigbjørn Obstfelder (1900/2001), en kronikk om Obstfelders roman av Tore Renberg (2000), poesisamlingene God morgen og godnatt av Nils-Øivind Haagensen (2013) og Vannfall av Atle Håland (2017), samt Bjarte Breiteigs essaysamling Den andre viljen (2016). Etter å ha lest og gjort meg kjent med litteraturen valgte jeg å arbeide videre med et essay av Breiteig og Espeviks roman. 
tenkningen, spørsmålene og tolkningene. Kjelaas skriver at hun «opplever aldri å ha ferdigformulerte analyser og fortolkninger som kan skrives «ut»» (Kjelaas 2015). Hun poengterer også at ved å begrense oss til «et nøkternt IMRaD-språk» kan personligheten i språket og finessene tapes (Kjelaas 2015) ${ }^{6}$. Med et konvensjonelt språk kan også forståelsen bli konvensjonell (Kjelaas 2015). Den foreliggende artikkelen følger ikke konsekvent en IMRaD struktur, og den har til tider et personlig språk. Det betyr ikke at jeg mener et konvensjonelt, mer nøkternt og entydig språk ikke er viktig, og jeg benytter meg også av det, men det betyr at et konkret og kreativt språk trengs i tillegg, både når det gjelder språket i litteraturen jeg benytter og hvordan jeg uttrykker meg i artikkelen og strukturerer den. Med sin bakgrunn blant annet i sakprosastudier formulerer Anders Johansen mye av det jeg opplever som det teoretiske arbeidet med denne artikkel i uttrykket «en sammenhengende tankeanstrengelse» (Johansen 2019: 24). Det omfatter å lete etter materiale, og å søke hjelp fra blant annet faglige begrep jeg kjenner til eller finner fram til, når behovet for «å tenke seg om i mer generelle vendinger» innfinner seg (Johansen 2019:24_- 25).

\section{ET ESSAY OM TRO}

Med disse tankene om bruk av skjønnlitteratur og essays som bakgrunn vil jeg fortsette med å gi min forståelse av hvordan Bjarte Breiteig i essayet Min tro, eller: Viljen til teksten skriver fram en eksemplifisering av tro. Essayet mener jeg kan benyttes som eksempel på en språkliggjøring av tro, og kan gi et innblikk i hva en elev kan stå overfor av utfordringer når hun skal språkliggiøre en religiøs tro innenfor skolens offentlighet. I essayet tolker han den skjønnlitterære skriveprosessen som en trosakt, og han bruker filmen Andrej Rubljov (1966) av Andrej Tarkovskij for å gi leseren en forståelse av hva en slik trosakt går ut på (Breiteig 2016).

Bjarte Breiteig konsentrerer seg om filmens siste del, det han kaller en slags film i filmen, og han mener denne delen tematiserer troens avgjørende betydning for skaping av kunst. Selv om det er tro og tvil i forbindelse med skaping av kunst essayet til Breiteig handler om, så mener jeg det er vanskelig å ikke lese essayet som i spill med både kunst som trosakt og religiøs tro. Breiteig forteller i essayet om hvordan filmens fiktive hovedperson, Boriska, i året 1413 leder støpingen av en ny kirkeklokke. Boriska satser høyt ved at han selv ber prinsens menn om å få oppdraget, et oppdrag som er kostbart og som krever både en enorm håndverksmessig presisjon og innsats på grensen til det umulige for arbeiderne. Dessuten nærmer vinteren seg, noe som gjør at Boriska må ta både snarveier og stor risiko, og mislykkes han, vil det koste ham livet (Breiteig 2016:147). Boriskas trumfkort

6 IMRaD står for Introduction - Method - Results - and - Discussion. På norsk Introduksjon - Metode Resultater - og - Diskusjon (IMRoD) 
er at han er sønn av den gamle støpemesteren, og at han «er den eneste som kjenner farens teknikker, og viktigst: den hemmelige legeringen for bronse som faren hvisket ham i øret før han døde» (Breiteig 2016:147). Breiteig skildrer hvordan Boriska med stor arroganse og tro på egen intuisjon setter de gamle arbeidernes erfaring til side og minner alle på, når de er i ferd med å gi opp, at han har den hemmelige kunnskapen som trengs. Breiteig mener at det i filmen skapes assosiasjoner til byggingen av Babels tårn, og han beskriver hvordan klokken til slutt avdukes som «et fremmedlegeme mellom jord, stein og leire» (Breiteg 2016:148). Klokken er et symbol for et folk som er hardt prøvd og «bundet til jorden», den har en åndelig betydning, skriver Breiteig. Lyden av klokken, når den er ferdig, vekker glede. (Breiteig 2016: 148.) Idet de første slagene lyder fra klokken, jobben er fullbragt, flyttes filmens oppmerksomhet over på Boriska som ligger i en gjørmepøl, utslitt, og gråtende. Nå avsløres sannheten, den at Boriska aldri har kjent til farens hemmelighet, den hemmelige legeringen, teknikken som den gamle støpemesteren brukte for å støpe klokker. Det hele har vært en bløff fra Boriskas side. Han har ikke arvet noe kunnskap om støpearbeid, og han har ikke hatt noen garanti for å lykkes med støpingen av klokken. Følgene kunne blitt fatale, som Breiteig uttrykker det. (Breiteig 2016:149.) Breiteig mener at i filmen ligger Tarkovskijs «tro på sitt eget ennå-ikke-eksisterende kunstverk som må bære hele det apparatet som skal til for å lage kunstfilmer av Andrej Rubljovs format» (Breiteig 2016:150).

Liksom for klokkestøperen Boriska var Tarkovskijs filmatiseringer dypest sett en tro og en lengsel etter å skape film som favnet «selve livsgåten», mener Breiteig, det var ingen kunnskap Tarkovskij kunne bygge på, og han hadde slik sett heller ingen garanti for at han ville klare å skape filmene (Breiteig 2016:151). Det fantes ikke noe fundament, bare tro. Troens paradoks, skriver Breiteig, er at du må allerede tro for å kunne tro. Tarkovskij mente at gjennom trosakten trådte filmens egen vilje fram, det han forstod som et mirakel. Fram til filmens egen vilje trådte inn, var filmskapingen først og fremst godt håndverk og hardt arbeid. Når filmens egen vilje trer inn, skjer det plutselig, og den snur om på ting og «(t) he material came to life». (Breiteig 2016:152.) For å komme så langt må han ha tro, og han må på et vis holde på troen, nærmest bløffe troen, når han i perioder mister den. «Man må hengi seg, uten å vite nøyaktig til hva, eller om det vil bære» (Breiteig 2016:153). Lidenskap og lengsel etter å kunne favne hele livsgåten er det som holder den som tror «flytende på et dyp man ikke kan fatte», skriver Breiteig. «Først da kan man ha håp om å få kjenne en vilje større enn ens egen» (Breiteig 2016:153).

Med den litterære kraftanstrengelsen bak essayet, spillet mellom flere parallelle fortellinger, får Breiteig gitt sin antydning om hva tro kan handle om. I dette essayet er det fortellinger om ham selv og hans skriveprosesser, fortellingen om 
Tarkovskijs filmatiseringsprosesser og fortellingen om den fiktive figuren Boriskas støpeprosesser som er satt i bevegelse. I spillet mellom de tre fortellingene skaper Breiteig et essay som gir oss en språkliggjøring av tro. Den anstrengelsen han gjør for å få til dette, mener jeg mer enn antyder hvor krevende det kan være for elever med en religiøs tro å både språkliggjøre troserfaringen for seg selv og for andre i skolen.

Å arbeide med en tekst av Bjarte Breiteig og hans måte å språkliggjøre tro på vekker også en nysgjerrighet på om det finnes en vei til samtale med elever om religiøs tro som går veien om fortellinger de vil benytte for å språkliggjøre tro? Hvordan settes flere fortellinger i spill? Hva føyer eleven til de fortellingene som allerede eksisterer, som de er kompetente på?

\section{EN ROMAN OM RELIGIØS TRO - OG OM TVIL OG EN SEKULÆR HVERDAG}

Hvis religiøs tro skal språkliggjøres i en offentlig samtale, så er det kanskje ikke bare troen som skal språkliggjøres, men også elevens bevegelse i sitt liv mellom det hellige og sekulære (Calhoun mfl. 2011:10). Dessuten hvordan tro kan stå i et forhold til tvil. Jeg skal derfor fortsette med romanen Hva ville Johannes gjort? der jeg mener forfatteren Thomas Espevik bidrar til å eksemplifisere en språkliggiøring av det komplekse forholdet mellom hellig og sekulær hverdag, og mellom tro og tvil (Espevik 2017).

La meg ta det siste først, språkliggjøring av tvil som står i et slags gjensidig forhold til religiøs tro. I siste del av romanen som heter Min tro går fortelleren i romanen, som er Johannes, fra å fortelle om sin oppvekst slik det blir gjort i første del av boken til å fortelle om sin nåværende religiøse tro. Jeg leser den siste delen av romanen som et slags messende crescendo der styrken i rivninger mellom tvil og religiøs tro øker til et nivå der den nærmest sprenges. I de siste linjene griper Johannes til en rituell kirkelig tekst som får funksjon som et hvileskjær, inntil videre, for en tro som av og til faller til ro, men som fort jages videre av paradokser og manglende sammenheng. Jeg har tillatt meg å nappe ut noen av utsagnene i teksten, slik de følger fra begynnelse til slutt, noe som på sett og vis er en brutal handling mot Thomas Espeviks roman, men som også er min eneste mulighet hvis jeg skal spille noe av kraften i Min tro inn i en fagtekst ${ }^{7}$. Slik følger mine utsnitt fra Espeviks tekst, og jeg håper de sporer til å oppsøke teksten i sin helhet:

Jeg vokste opp i en kristen familie. Jeg ble dopt da jeg var noen måneder gammel. I 18-årsalderen vurderte jeg å dope meg på nytt, men jeg slo det fra meg. [...] Jeg var ikke redd for å do for tvilen kom. Jeg vil ikke (og jeg kan ikke forklare hvorfor) donere bort organene mine når jeg dor. [...] Jeg har aldri fornektet Jesus. [...] Jeg ser ikke på

7 Thomas Espevik har fått lese og uttale seg om utdragene og konteksten de står innenfor. 
Bibelen som en laerebok i naturvitenskap, jeg ser heller ikke på den som Guds ord, men jeg tror den sier noe om hvem Gud er. [...] For tenkte jeg på meg selv som en disippel. Nå er troen min så skjør at det ikke ville falle meg inn å prakke den på noen. [...] Når jeg snakker om tvilen min kan jeg få en folelse av at Gud tyvlytter. [...] Jeg klarer ikke å forstå hvordan alt det som finnes, ikke kan vare skapt av en Gud. [...] Jeg tviler mer på troen min enn på Gud [...]. Jeg har en trang til å tro på Gud, en trang til å tro at døden tar slutt. [...] Det er flere år siden jeg hadde kors rundt halsen. Jeg har ikke andre guder enn Deg. Selv om jeg har loert meg å banne, klarer jeg fortsatt ikke å si herregud. Søndag er ikke en hellig dag for meg. [...] Flere ganger har jeg opplevd at folk i min omgangskrets har latterliggjort kristne uten at de har visst om min tro. [...] Jeg liker ikke å snakke om troen min med ateister. [...] I slutten av tenårene kjøpte jeg en caps, noen gensere og et par T-skjorter fra USA med kristne motiv. Mange vil si jeg har forandret meg de siste årene, og det er helt sant. [...] Når jeg horer en god godspellåt, er det enklere å tro på Gud. [...] Jeg kan ikke gi et psykologisk eller teologisk tilfredsstillende svar på hvorfor jeg tror på Gud. Jeg tenker, altså er jeg. Jeg ber, altså tror jeg. Jeg er ikke komfortabel med begrepet kristen. [...] Jeg lurer på om noen ateister er like redde at Gud er der, som jeg er for at han ikke er der. [...] Jeg trenger ikke en tro som får alt til å gå opp, jeg trenger en tro som gjor at jeg ikke er redd. [...] Jeg tenker ofte at jeg burde starte og avslutte dagen med Fadervår. [...] Jeg har fire navn på Gud [...] De menneskene jeg synes har mest interessant å si om tro, er ofte mennesker som har forlatt troen. [...] Noen ganger hjelper det å be, men oftest blir jeg bare trøtt. Jeg har ofte lett uten å finne, bedt uten å fä, banket på uten at det har blitt lukket opp for meg. [...] For noen inneborer det en frihetsfolelse å komme frem til at Gud ikke finnes, for meg ville det ha vart en tragedie. Noen ganger ber jeg Gud om å fylle meg med Den hellige ånd, som om han forelopig bare har latt meg få en liten del, en bitte liten ånd langt inne i kroppen min. Jeg tenker ofte på hva som vil skje om jeg slutter å tro, [...] Men enn så lenge tror jeg på Gud Fader, den allmektige himmelens og jordens skaper. Jeg tror på Jesus Kristus [osv.] Amen.

Jeg velger å gi utdragene overfor betegnelsen utsagn om tvil. De er relativt kraftfulle, vil jeg si. Det er muligens en vilje til å slippe tvilen til det dreier seg om, og en styrke til å tro selv om det er gitt «fritt fram for» både paradokser og mangel på sammenheng. Paradoksene og tvilen inntar så å si hele bakgrunnen, mens troen er en liten prikk i forgrunnen. Men den utgjør forgrunnen. Jeg tenker igjen på elevene og på invitasjonen til å delta i de offentlige samtaler, i skolen, med sin religiøse tro. Hvordan gjør de det, innenfor en rasjonell samtale? Å delta med tvil og tro som slåss med hverandre. Teksten til Thomas Espevik minner om tekster av forfatteren Thomas Bernhard som er som litterære musikkstykker, de har rytme og intensitet som kjennes like mye som de forstås, de dirrer som en taktfast bass i kroppen. Jeg blir i tvil om hvordan en elev kan gå inn i offentlige samtaler med 
sin tro - og tvil, når språkliggjøringen muligens gjøres best som slam, rapp, eller som de heseblesende tekstene til Thomas Bernhard og den besvergende teksten til Thomas Espevik. Det er alt koblet opp til toner, stemmeleier eller rytmer. Det emosjonelle og estetiske er meningsbærende, det er viktige sider ved tenkning og kommunikasjon (Gripsrud 2018:46). Slik sett hører det også hjemme innenfor et rasjonalitetsbegrep, et utvidet et. Jeg er enig med Gripsrud, men hvilken elev har mot nok til å framføre sin tro og tvil med et iscenesatt brøl eller med rytme, hvisking og et avsluttende crescendo? Noen kanskje. Men trolig ikke mange. Det er ikke lett å skulle språkliggjøre, på et emosjonelt og estetisk vis, sin religiøse tro og tvil. Men det finnes mulighet for tilbaketrekning. Til å unndra seg samtalene og leite etter estetiske uttrykk. I skjønnlitterær litteratur med en musikalsk nerve. I musikk med en skjønnlitterær nerve. I en annen type offentlighet kan troen språkliggjøres som en slags knuffing med tvilen.

Nå snur jeg og går framover, mot første del av Thomas Espeviks bok. Calhoun m.fl. skriver om Charles Taylor at når han refererer til sekulær tro og sekulære forestillinger som realiteter $\mathrm{i}$ vår tidsalder, så gjelder ikke dette bare som realiteter for ikke religiøse mennesker, men også for religiøse (Calhoun mfl. 2011:10). Når jeg begynner lese- og skrivearbeidet for den foreliggende artikkelen, innser jeg også relativt fort at sekulær tro og livsførsel er like mye til stede i livet til elever med en religiøs tro som det religiøs tro og livsførsel er. Calhoun m.fl. understreker at selv et religiøst troende menneske vil i vår tid ha forestillinger om eller en tro på en verden som eksisterer bare for seg selv, uten guddommelig inngripen, der for eksempel forestillinger om naturlover og effektiviteten i juridiske og teknologiske system inngår (Calhoun m.fl. 2011:10). Det felles etymologiske opphavet til begrepene sekulært er århundre, saeculum (latin) og siècle (fransk), og alder. Det ligger en forståelse i det av at sekulære oppgaver kan knyttes til tid og alder, de jordiske eller verdslige affærer, det forgjengelige (Calhoun m.fl. 2011). I første del av Thomas Espeviks roman handler det mye om Johannes og familiens sekulære affærer, men i stedet for å omhandle hvordan en kristen familie også tror på juridiske og teknologiske system, naturlover osv. så er det heller hvordan familien lever i en sekulær virkelighet der de ser på fjernsyn, spiller dataspill, bryter lover, og der ungene utforsker insekter på lite naturvennlige vis (Espevik 2017). Det er med andre ord det sekulære livet av det mer usminkete slaget det dreier seg om. Hovedpersonen Johannes farter inn og ut av husene til kameratene Kristoffer og David der religion ikke er et tema, de spiller Nintendo på gutterommene, ser James Bond uten å få lov til det, og de konkurrerer om å ha sett film med flest antall drepte. Moren vil helst at Johannes spiller engelske dataspill for å lære seg mer engelsk, det er nyttig for framtiden. Når familien får kabel-TV, ser Johannes og faren Baywatch sammen, hver eneste dag. Når de skal på fotballkamp, «lemper» faren det litt til i billettluka, for da «[...] var David plutselig broren min, det var i hvert fall det 
pappa sa til mannen i luken da han skulle betale for billettene til Viking-kampen» (Espevik 2017:35) Når Johannes har tjuvfisket, i all hemmelighet, reingjør faren fisken med et lurt smil om munnen. I nabohuset mishandler naboen hunden sin, ungene utforsker insekter på et dyreplagende vis, og unger plager andre unger som de oppfatter som svake. Men når Johannes har lært å si «jævla», roper faren at «VI ER KRISTNE» (Espevik 2017:22). Om kvelden ber faren til Johannes sammen med dem for alle i verden og synger en sang. I jula skal de synge kristne julesanger, sier moren, for julen er kristen. Frisører finnes, sier Johannes' lillebror, og engler. Selv om det er søndag, vil moren at Johannes skal få fiske. Moren til Kristoffer, en av Johannes sine kamerater, er redd for at Kristoffer skal bli hjernevasket etter å ha vært med Johannes på en kristen leir. Når Johannes ser tilbake på oppveksten, så stiller han det retoriske spørsmålet «Hvem som presenterte meg for Gud?» (Espevik 2017:23.) Og han svarer: «Altså, han har jo vært der hele tiden, i bøkene mine, i sangene våre, i munnen til mamma og pappa, på den ene skulderen min og inni hjernecellene mine» (Espevik 2017:23). I den siste delen av romanen, Min tro, skriver Thomas Espevik om Johannes at «Jeg skjønte ikke at troen gjorde meg annerledes før jeg begynte på ungdomsskolen og noen så at jeg foldet hendene for å be en liten bønn i et friminutt. De spurte om jeg ba, jeg sa ja, og så lo de. I tiden etter sluttet jeg å være sammen med dem som ikke var kristne, jeg gikk på færre fotballtreninger, prioriterte heller bedehuset [...]» (Espevik 2017:121) Før den tid er mye likt for Johannes, hverdagene er knyttet til det jordiske, den er lik på godt og vondt med de andres hverdag, mens religiøs tro også er en like selvfølgelig del av det hele. Sammenfattet og forstått innenfor denne artikkelens kontekst, så gir Thomas Espevik et uttrykk for en religiøs tro der troen spiller seg ut mot tvil, og sekulær hverdag veksler med det hellige. Dette får han til fordi han behersker en ordkunst som er det litteraturviteren Vigdis Ystad kaller «overlegen som uttrykk for menneskelege innsikter og livsrøynsler.» (Ystad 2019:13). Men det kan som sagt trolig også si oss noe om hvor krevende det kan oppleves for en elev å skulle uttrykke tilsvarende religiøse troserfaringer stilt overfor de offentlige samtaler i skolen.

\section{INKLUDERING, OVERSETTELSE OG KJENSLE}

\section{- EN AVSLUTNiNG}

Boka Rethinking Secularism (2011) reiser spørsmålet om i hvilken grad en offentlig samtale er integrerende hvis innsikt og kreative ressurser fra de religiøse stemmene holdes utenfor fordi de regnes som uforenlig med en sekulær offentlig samtale:

"At stake in such discussions is whether the democratic public sphere (a) loses its capacity to integrate public opinion in its decision-making structure if it can't include religious voices and (b) is deprived of possible creative resources, insight, and ethical orientations if it isn't informed by ideas with roots in religion.» [...]

(Calhoun m.fl. 2011:18). 
Diskusjoner om de religiøse stemmenes potensial som kreative, innsiktsfulle og etisk interessante bidragsytere til de offentlige demokratiske samtalene kan også gå hånd i hånd med et spørsmål om hvilke muligheter de religiøse stemmene har for å delta. En måte å sammenfatte diskusjonene rundt spørsmålet på er at religion på den ene siden oppfattes som å kunne tilby et annet språk som kan berike offentlige samtaler, mens det på den andre siden forventes at religion blir oversatt til et sekulært språk for å kunne delta. Diskusjonen om det som kalles «oversettelsesproblemet» har blant annet gått mellom filosofene John Rawls og Jürgen Habermas:

Rawls initially excluded religious reasons from public debates; late in life, he reconsidered his prior position and argued that they should be included as long as they could be translated into secular terms. Habermas has gone further, worrying that the demand for «translation» imposes an asymmetrical burden; he is also concerned not to lose religious insight that may still have liberatory potential. [...] These [public expressions of religion] may be key resources for the creation of meaning and identity; secular citizens can learn from religious contributions to public discourse (not least when these help clarify intuitions that the secular register has not made explicit). [...]

(Calhoun m.fl. 2011:19).

Sammenfattet forstår jeg dette som en diskurs om den religiøse troens potensial og hvilke muligheter den har for å trekkes inn i de offentlige samtaler uten å tømmes for sitt potensial gjennom en «oversetting», eller ved å måtte tilpasse seg eksisterende forståelser for å kunne delta. Denne typen diskurser mener jeg kan gi gode forståelser av noen av de utfordringene elever kan møte i skolens offentlige samtaler, hvis de har en religiøs tro. Eskil Skjeldal skriver om forfatteren Jon Fosse som «sit med mykje teologisk, estetisk og filosofisk kunnskap. Men han har ei beinvegs kjensle for mysteriet Gud» (Fosse, Skjeldal 2015:7). Tro forstått som følelser, stemninger, mysterier kan med andre ord være en størrelse som dreier seg om noe annet enn kunnskap ${ }^{8}$. Hvordan kan elever med et religiøst språk, med religiøse erfaringer og forståelser, tre inn og samtale med et fellesskap der det eksisterende språket og forståelsene er helt annerledes? Hvordan er det mulig at det kan skje? Ved å gå veien om en utvidet rasjonalitet og ved å støtte meg på ordkunst og ordkunstnere som kan være vår egen uttrykksevne overlegen, også når det gjelder religiøse erfaringer, har jeg forsøkt å gjøre språklig min forståelse av de utfordringene elever med en religiøs tro kan stilles overfor i de felles samtalene i skolen.

8 Skjeldal skiller slik jeg forstår det mellom kunnskap og erfaring (Fosse, Skjeldal 2015). Jeg har i denne artikkelen brukt kunnskapsbegrepet på samme vis, men kanskje kunne jeg også brukt begrepet erfaringsbasert kunnskap om «kjensler». 


\section{LitTERATUR}

Biesta, Gert J. J. 2009. «Against learning.» I: Gert J. J. Biesta (red.) Beyond Learning. Democratic Education for a Human Future. Paradigm Publisher. London

Botvar, Pål Ketil. 2010. «I skjæringsfeltet mellom det offentlige og det private.» I: Pål Ketil Botvar, Ulla Schmidt (red.) Religion i dagens Norge. Mellom sekularisering og sakralisering. Universitetsforlaget. Oslo

Breiteig, Bjarte 2016. Den andre viljen. Aschehoug. Oslo

Calhoun, Craig., Juergensmeyer, Mark., van Antwerpen, Jonathan 2011. «Introduction» I: Craig Calhoun, Mark Juergensmeyer, Jonathan van Antwerpen (red.). Rethinking Secularism. Oxford University Press. New York

Domínguez, Juan Pablo 2016. «Introduction. Religious toleration in the Age of Enlightenment.» History of European Ideas 43:4, s273_- 287, DOI: 10.1080/01916599.2016.1203590

Espevik, Thomas 2017. Hva ville Johannes gjort? Flamme Forlag. Oslo

Fosse, Jon., Skjeldal, Eskil 2015. Mysteriet i trua. Ein samtale mellom Jon Fosse og Eskil Skjeldal. Samlaget. Oslo

Flensner, Karin Kittelmann, von der Lippe, Marie 2019. «Being safe from what and safe for whom? A critical discussion of the conceptual metaphor of 'safe space'.» Intercultural Education Volum 30, s275_-288. https://doi.org/10.1080/ 14675986.2019.1540102

Furseth, Inger 2015. «Innledning.» I Inger Furseth (red.) Religionens tilbakekomst $i$ offentligheten? Religion, politikk, medier, stat og sivilsamfunn i Norge siden 1980-tallet. Universitetsforlaget. Oslo

Gilliam, Laura., Gulløv, Eva 2015. Siviliserende institusjoner. Om idealer og distinksjoner i oppdragelse. Fagbokforlaget. Oslo

Gripsrud, Jostein 2017. «Offentlighet. Idealer, realiteter og tilfellet Norge.» I Jostein Gripsrud (red.): Allmenningen. Historien om norsk offentlighet. Universitetsforlaget. Oslo

Henriksen, Jan-Olav., Schmidt, Ulla (2010). «Religionens plass og betydning i offentligheten» I Pål Ketil Botvar, Ulla Smith (red.). Religion i dagens Norge. Mellom sekularisering og sakralisering. Universitetsforlaget. Oslo

Håland, Atle 2017. Vannfall. Flamme forlag. Oslo

Kjelaas, Irmelin 2015. 30. november. Forskerforum. Kronikk. https://www.forskerforum.no/alt-jeg-gj-r-er-formidling/

Library Foundation of Los Angeles 2012. Slavoj žižek. God in Pain. Inversions of Apocalypse. In Conversation with Jack Milen [videoklipp]. Hentet fra: https:// www.youtube.com/watch?v=sQ3g2zS6Tuk 